James Windle (2016): Security trumps drug control: How securitization explains drug policy paradoxes in Thailand and Vietnam, Drugs: Education, Prevention and Policy, DOI: $10.3109 / 09687637.2016 .1140720$

\title{
Security Trumps Drug Control: How Securitization Explains Drug Policy Paradoxes in Thailand and Vietnam
}

The final version of the paper as published in the print edition can be found at: http://www.tandfonline.com/doi/full/10.3109/09687637.2016.1140720

\begin{abstract}
This paper investigates the paradoxes inherent in Thai and Vietnamese drug policies. The two countries have much in common. Both are ultra-prohibitionist states which employ repressive policies to contain drug markets. Their policies have, however, diverged in two key areas: opium suppression and harm reduction. Thailand implemented an effective intervention to suppress opium farming centred upon alternative development, whereas Vietnam suppressed opium production through coercive negotiation with nominal alternative development. Vietnam has embraced elements of harm reduction, whereas Thailand has been slow to implement harm reduction policies. This paper hypothesises that these two differences are largely a product of their perceived relationship to security. The two cases demonstrate how once an issue is securitized the ultra-prohibitionist rules of the game can be broken to allow for more humane and pragmatic policies.
\end{abstract}

\section{Introduction}

This paper investigates the paradoxes inherent in Thai and Vietnamese drug policies. The two countries have much in common. Situated in close proximity to some of the world's largest sources of heroin and amphetamine-type stimulants (ATS), their most widely consumed drugs are generally considered amongst the most harmful (Nutt et al., 2010). ${ }^{\text {i }}$ Furthermore, the suppression of drug consumption and trade is high on both states agendas. Indeed, both could be described as ultraprohibitionist states which employ repressive policies that often contravene international human rights law.

Vietnam has, however, started to overcome its punitive predisposition in the face of one of Asia's worst ongoing HIV epidemics to gradually introduce harm reduction policies; ${ }^{\text {ii }}$ which have contributed to a reduction in HIV. Thailand, on the other hand, has been slow to implement harm 
James Windle (2016): Security trumps drug control: How securitization explains drug policy paradoxes in Thailand and Vietnam, Drugs: Education, Prevention and Policy, DOI: $10.3109 / 09687637.2016 .1140720$

reduction practices. That is, Vietnam is moving towards a more effective and humane policy whereas Thailand continues to rely on less effective and more repressive policies aimed at forcing abstinence.

Both are amongst a small number of states to have suppressed the illicit production of opium (see Windle, 2016). Thailand's zero tolerance approach to consumers and distributors is paradoxically dovetailed by its strong identity as a model of humane drug crop suppression through alternative development, supported by law enforcement. The core of Vietnam's suppression effort, on the other hand, was coercive negotiation by the military with minimal support for alternative development. That is, Thailand implemented a humane policy, whereas Vietnam relied on more repressive policies aimed at the immediate cessation of opium farming. ${ }^{\text {ii }}$

This paper will explore the similarities and differences between the two countries drug policies and provide a hypothesis on what led to such different routes. The paper begins by exploring the similarities between the two states in terms of national drug markets and, their overarching philosophies and drug policies. This is followed by an exploration into the two main differences: harm reduction and opium suppression. The concluding section employs the securitization model to develop a tentative hypothesis that security concerns have overshadowed drug concerns. That is, more humane policies have been implemented less for the benefit of consumers or farmers and more as a response to the non-traditional security threats of HIV, and the more traditional security threats of insurgency and border control. Importantly, the two cases demonstrate how once an issue is securitized the ultraprohibitionist rules of the game can be broken to allow for more humane policies: a process seldom documented in the literature.

\section{Similarities}

This section will explore three main similarities: ultra-prohibitionist philosophical foundation, HIV amongst people who inject drugs, and the use of compulsory treatment for drug users. 
James Windle (2016): Security trumps drug control: How securitization explains drug policy paradoxes in Thailand and Vietnam, Drugs: Education, Prevention and Policy, DOI: 10.3109/09687637.2016.1140720

\section{Philosophical foundation}

Combating drug consumption and smuggling continue to be high priorities for both Thailand and Vietnam (see Bangkok Post, 2014; Hayashi, 2013; Vuong et al., 2012; Windle, 2015, 2015b). Both states drug policies are founded upon conservative and zero-tolerance philosophies (Vuong et al., 2012) that might by termed ultra-prohibitionist. Such policies receive strong support from the general public (Open Society, 2007; The Nation, 2014): as they do in other ultra-prohibitionist states such as China, Russia and the U.S. (see Levine, 2003; Zhang and Chin, 2015). Thai and Vietnamese societies are heavily influenced by philosophies / theologies which dictate that the individual should consider the needs of the country and family before their own: Communism and Confucianism in Vietnam, and Buddhism in Thailand. As such, perceived addicts 'have always been seen in a negative light as selfindulged, selfish, and spoiled' (Hayes-Larson et al., 2013:2). In fact, prohibitionist norms have much longer histories in the region than in either Europe or North America: due to the influence of Buddhism and Confucianism (Windle, 2014).

Since the early-1990s Vietnam's official and publicly-stated view of illicit drugs has been that they are a 'social evil' to be eradicated (see Government of Vietnam, 1992: article 61). The 2000 Law on Preventing and Combating Narcotic Drugs identified drugs as:

... a major threat to the entire society, doing harm to human health, causing offspring degeneration, degrading human dignity, disrupting family happiness, and gravely affecting social order and safety and national security (Government of Vietnam, 2000).

Vietnam has employed repressive policies to suppress this 'social evil': an estimated 700 prisoners were on death row as of 2014, the majority for drug offences (The Telegraph, 2014).

While Thailand calls for compassion towards drug users in its official drug control strategies (see ONCB, 2007) high level politicians have consistently demonised drug market participants. The abuses of the 2003 'War on Drugs' - in which an estimated 2,819 people were killed (Human Rights 
James Windle (2016): Security trumps drug control: How securitization explains drug policy paradoxes in Thailand and Vietnam, Drugs: Education, Prevention and Policy, DOI: $10.3109 / 09687637.2016 .1140720$

Watch, 2004) - were a direct result of political pronouncements. In one speech, for example, Prime Minister Thaksin stated:

You must use iron fist against drugs traffickers and show them no mercy. Because drug traffickers are ruthless to our children, so being ruthless back to them is not a bad thing ... If there are deaths among traffickers, it is normal (cited in Human Rights Watch, 2009: no page).

In 2008, the 'War on Drugs' was reinstated with Thailand's interior minister, Chalerm Yubamrung, stating that the crackdown would continue even if 'thousands of people have to die' (cited in Werb et al., 2009: no page). Then, in September 2014, armed police and army personnel conducted a door-to-door operation in which potential drug users were forced to take drug tests: 83 users and 22 'small-time dealers' were arrested. The users were imprisoned in compulsory treatment centres (Bangkok Post, 2014).

In summary, both Thai and Vietnamese drug policies are founded upon ultra-prohibitionist philosophies which demonise drug users and support zero tolerance approaches. The following section discusses a controversial consequence of this philosophical foundation: compulsory treatment centres.

\section{Compulsory treatment centres}

In Thailand and Vietnam, possession and consumption of illicit drugs can result in arrest and incarceration in compulsory treatment centres (Pearshouse, 2009; Vuong et al., 2012). In 2010, approximately 102,291 people were incarcerated in 98 compulsory treatment centres in Thailand (ONCB, 2011); approximately 24,155 were incarcerated in 123 centres in Vietnam (UNODC, 2011).

Most are imprisoned for around three to six months in Thailand or a maximum of two years in Vietnam, although the detention period can be extended upon review. Treatment often centres upon intensive physical exercise, forced labour, vocational training, therapeutic community group 
James Windle (2016): Security trumps drug control: How securitization explains drug policy paradoxes in Thailand and Vietnam, Drugs: Education, Prevention and Policy, DOI: $10.3109 / 09687637.2016 .1140720$

discussions and/or lectures demonising drugs (see Csete et al., 2011; Human Rights Watch, 2011; Pearshouse, 2009; States News Service, 2014; WHO, 2010). Cruel, inhuman and degrading treatment is common (Human Rights Watch, 2011; also Pearshouse, 2009; WHO, 2010). As centres fail to address underlying psychological or social problems, relapse rates tend to be high (Tyndal, 2010; also

Csete et al., 2011; UNODC, 2011, 2012). Furthermore, the threat of arrest and, subsequent imprisonment and forced detoxification in centres inflate risky injecting behaviour and prevents access to health care; including HIV/AIDS treatment and prevention (Pankonin et al., 2008; also Hayashi, 2013; Jardine et al., 2012; Kerr et al., 2014).

Encouragingly, Vietnam has declared its intention to reduce the number of centres in its 2013

Drug Rehabilitation Renovation Plan and increase resources for community-based voluntary treatment (Government of Vietnam, 2014; UNODC, 2012a). While Vietnam is attempting to fix the compulsory treatment system - rather than eliminate it altogether (see Thai News Service, 2014) Thailand has made no moves towards reform.

\section{HIV amongst people who inject drugs}

While prevalence of HIV has dropped from its peak in the early-2000s (Government of Vietnam, 2013), Vietnam continues to have one of Asia's fastest growing HIV rates (Tran, 2013). At the start of 2014 an estimated 256,000 people $-0.26 \%$ of the general population aged over 15 - were living with HIV (Government of Vietnam, 2013). Injecting drug use is the primary means of contracting HIV: Approximately $60 \%$ of all new HIV cases are contracted through needle sharing (Zhang et al., 2014) and injecting drug use is rising (UNODC, 2014a).

Thailand has been identified as a 'High Priority Country' by UNODC's HIV Programme (UNODC, 2013). In 2013, there were an estimated 430,000 people $-1.1 \%$ of the general population living with HIV (UNAIDS, 2014). While half what it was in the mid-1990s the prevalence rate remains amongst the highest in Southeast Asia (Avert, 2014). The decline in HIV transmissions have been attributed to extensive prevention and treatment campaigns. Thailand is often seen as a model amongst developing countries in the provision of antiretroviral therapy (Human Rights Watch and 
James Windle (2016): Security trumps drug control: How securitization explains drug policy paradoxes in Thailand and Vietnam, Drugs: Education, Prevention and Policy, DOI: 10.3109/09687637.2016.1140720

Thai AIDS Treatment Action Group, 2007) and HIV prevention. For example, sexual transmission of HIV declined by over $80 \%$ between 1991 and 2001; largely due to information campaigns and condom distribution (Csete et al., 2011). The World Bank (2011:4) has referred to its antiretroviral programme as 'the most progressive and comprehensive ... in the region' whilst noting that it is 'remarkable how poorly Thailand has responded to the HIV epidemic among injection drug users'.

From 2010, however, the rate of decline began to slow and, is rising among young people and at risk groups (Government of Thailand, 2014; UNICEF, 2014): including people who inject drugs. And intravenous drug use is rising; especially in southern provinces (Malikaew, 2014). While unsafe sex remains the primary means of contracting HIV in Thailand, intravenous drug use is a significant mode of transmission (Government of Thailand, 2014): in 2012, the Thai Government estimated that $25.2 \%$ of people who inject drugs were living with HIV (Government of Thailand, 2014). And in 2009, the government estimated that 40,300 people had injected drugs (UNODC, 2014a); an alternative estimate, however, places the number closer to 97,300 (MacDonald \& Nacapew, 2013).

\section{Differences}

The previous section has shown how Thailand and Vietnam are similar in a number of ways. Their most heavily consumed drugs are often considered amongst the most harmful to the individual and society. Both have been heavily impacted by HIV. Both are conservative in their approach towards illicit drugs, and focus much of their resources on, often repressive, law enforcement and compulsory treatment centres. This section will draw out two main differences: harm reduction and illicit opium suppression.

\section{Harm reduction in Vietnam}

From around 2005, the HIV epidemic slowly shifted the ruling Communist Party's perception of the drug problem. Many Communist Party leaders identified the unintended consequences of repressive 
James Windle (2016): Security trumps drug control: How securitization explains drug policy paradoxes in Thailand and Vietnam, Drugs: Education, Prevention and Policy, DOI: $10.3109 / 09687637.2016 .1140720$

law enforcement and became 'strong proponents' of harm reduction (Vuong et al., 2012: 322). The

2006 Law on AIDS/HIV Prevention and Control emphasized:

... encouragement of the use of ... clean syringes and needles, treatment of addiction to opium-related substances with substitute substances and other harm reduction intervention measures (Government of Vietnam, 2006).

The 2014 Plan for Socio-Economic Development called for scaling up of methadone maintenance and voluntary treatment services (State News Service, 2014) while the 2000 Law on Preventing and Combating Narcotic Drugs was amended in 2008 to provide support for the harm reduction measures proscribed in the Law on AIDS/HIV Prevention and Control. In 2009, the Penal Code was amended to characterize drug users as patients rather than criminals (Vuong et al., 2012).

Pilot methadone maintenance programmes - administered between 1997 and 2002 - were considered successful in reducing HIV and acquisitive crime and, improving the health of users and general public. Rolled-out nationally in 2008, methadone maintenance programs expanded and by early-2014 were available to 15,542 patients across 80 sites in 30 provinces and cities. The government has committed to expanding methadone access to 80,000 drug users by 2015 (Government of Vietnam, 2014; also Cates, 2013).

Vietnam runs needle exchange programs in most provinces. In 2012, it distributed 180 needles/syringes per injecting user (Government of Vietnam, 2014). While 180 needles per user is above the Asian regional median of 116, it remains below the UNAIDS recommendation of 200 (UNAIDS, 2014); although 12 of Vietnams 32 provinces have reached UNAIDS target (Zhang et al., 2014). The national ratio unfortunately dropped to 98 per injecting user in 2013 (Government of Vietnam, 2014). This reduction likely represents the end of funding for needle exchange programmes by the World Bank and UK Department for Foreign Development (DFID) in 2012 (Windle, 2015). Improved access to clean needles has reduced needle-sharing in many areas. Twenty six of 32 provinces in which DFID and the World Bank administered needle exchange programs witnessed a decline in HIV prevalence, no province reported a growth in HIV prevalence, and the project 
James Windle (2016): Security trumps drug control: How securitization explains drug policy paradoxes in Thailand and Vietnam, Drugs: Education, Prevention and Policy, DOI: $10.3109 / 09687637.2016 .1140720$

prevented an estimated 26,822 HIV infections (Zhang et al., 2014). Overall, the introduction of harm reduction programmes have contributed to a reduction in the HIV rate among people who inject drugs from $30 \%$ in the mid-1990s to $11.6 \%$ in 2013 (IRIN, 2014; also Nguyen \& Scannapieco, 2008).

Significant challenges and barriers to effective harm reduction remain. The Ordinance on Administrative Violations continues to categorise drug use as an administrative violation and, users are still frequently imprisoned in compulsory drug treatment centres (Vuong et al., 2012). The uniform and discriminatory attitudes of medical professionals in Vietnam and abusive police practices represent additional barriers. The prevalent police culture views forced detoxification as the only means of reducing the perceived threat drug users pose to society. Indeed, local police use harm reduction programs as mechanisms for identifying drug users and, the harassment and arrest of harm reduction workers is common (Hammett et al., 2008; Jardine et al., 2012; Windle, 2015b).

Attitudes among some in the Vietnamese police may be changing. For example, Lieutenant Colonel Lam Tien Dung of the People's Police Academy, stated at the 2014 International AIDS Conference that:

\begin{abstract}
Harm reduction approaches to HIV prevention among ... drugs users have been scientifically proven by public health experts, but cannot be successful without the active participation of law enforcement ... We used to think of these people as our targets, but now we see them as our partners. By working with HIV experts to develop strong police practices grounded in public health and human rights, we can help control the spread of HIV (States News Service, 2014).
\end{abstract}

Furthermore, the Vietnamese Communist Party used the 2014 World Drug Day to appeal for an end to the stigmatisation and discrimination of drug users (UNODC, 2014b). In short, while there remain barriers, partly attributable to entrenched cultural norms, Vietnam is moving towards a more harm reductionist position; even if it is some way off a wider national policy designed around harm reduction principles of pragmatism, humanistic values and a focus on harms (Hunt et al., 2003). 
James Windle (2016): Security trumps drug control: How securitization explains drug policy paradoxes in Thailand and Vietnam, Drugs: Education, Prevention and Policy, DOI: 10.3109/09687637.2016.1140720

\section{Harm reduction in Thailand}

Thailand has been slow to implement harm reduction practices. ${ }^{\text {iv }}$ Those that have been implemented have focused upon injecting heroin users, even though yaa baa - Thailand's most popular illicit drug is most commonly eaten or smoked. Indeed, there are few harm reduction services directed specifically at consumers of amphetamine-type stimulants: a situation common to many countries (Barrett et al., 2010; see Pinkham \& Stone, 2015). ${ }^{v}$

Thailand's coverage of clean needles is one of the lowest in Asia. In 2013 it distributed just 12.02 sets of needles per user; up from 9.79 in 2011 (Government of Thailand, 2014; also WHO, 2010). This is significantly lower than the Asian median of 116, the Vietnamese rate of 180 and UNAIDS recommended minimum of 200 (UNAIDS, 2014). Furthermore, there are very few needle exchanges: just 38 sites operated in 2013, down from 49 in 2010. The majority were based in Bangkok (Government of Thailand, 2014; also WHO, 2010).

While methadone has been available for substitution therapy since 2000 , treatment coverage has historically been low and largely limited to Bangkok (Fairbairn et al., 2012). Nonetheless, some pilot projects have been initiated in remote areas of northern Thailand and coverage is increasing. In 2013, there were 147 sites providing substitution therapy, up from 49 in 2009 (Government of Thailand, 2014). The majority of methadone is provided to assist detoxification over 45-to-90 day programmes: long-term methadone maintenance can only be prescribed after three failed attempts at abstinence. Furthermore, the lack of state subsidization makes it expensive (Fairbairn et al., 2012).

There are a number of barriers to accessing needle exchanges and substitution therapy. First, drug consumption remains a crime and the distribution of needles has been interpreted as promoting drug use. ${ }^{\text {vi }}$ Second, as health care providers often hold negative attitudes to people who inject drugs, many are slow to promote needles exchanges (Government of Thailand, 2014; Chan et al., 2008): which are often viewed as 'immoral', 'not Thai' or 'encouraging drug use' (Human Rights Watch and Thai Aids Treatment Action Group, 2007). Third, there tends to be a high police presence, and harassment of consumers and workers at treatment and harm reduction sites: $25.5 \%$ of a sample of 
James Windle (2016): Security trumps drug control: How securitization explains drug policy paradoxes in Thailand and Vietnam, Drugs: Education, Prevention and Policy, DOI: 10.3109/09687637.2016.1140720

435 people who inject drugs reported avoiding healthcare due to the threat of compulsory treatment

(Kerr et al., 2014).

Human rights groups have identified widespread use of cruel, inhumane and degrading treatment of individuals during arrest, pre-trail detention and incarceration. For example, $37 \%$ of a sample of 639 people who inject drugs in Bangkok reported being beaten or, less often, tortured by the police; often to coerce them into admitting false charges. In addition, extrajudicial killings by the police during the 2003 'War on Drugs' instilled a fear that is hard to shake off (Hayashi, 2013; also Tyndal, 2010). While the harassment of drug users and harm reduction workers parallels the experience of Vietnam, the impetus to change evident in Vietnam is missing from Thailand.

\section{Drug crop suppression in Vietnam}

There is a long tradition of opium production in Vietnam by some ethnic groups, who have cultivated opium poppies since migrating to the highlands from China in the early $/$ mid- $19^{\text {th }}$ century (Culas \& Michaud, 1997). In 1975, the government began procuring highland opium for domestic and export medicinal purposes. While the state stopped buying highland opium in 1985 , those who had been selling to the state continued producing opium: the majority was sold on the black market (Boonwaat, 2001). Opium production was, however, tolerated until prohibited in 1992; amidst concerns over rising domestic opium and heroin consumption (Rapin et al., 2003).

Crop substitution projects were established in the early-1990s. These state administered projects centred on contracts whereby the state agreed to compensate individual farmers or provide rural development in exchange for the immediate cessation of opium farming. While drug control was later mainstreamed into national highland development programmes, the level of development support remained spotty, sporadic, and considerably lower than in lowland areas (Windle, 2012b).

Indeed, the core of the opium suppression effort was 'coercive negotiations' (Windle, 2012b). From 1992, the official policy was to immediately eradicate opium poppies. So-called 'negotiated eradication' would begin with the distribution of propaganda on the harm of opium and promises of rural development assistance. Negotiations with farmers were conducted by the military. While the presence of the military implied coercion, reports also emerged that soldiers regularly threatened 
James Windle (2016): Security trumps drug control: How securitization explains drug policy paradoxes in Thailand and Vietnam, Drugs: Education, Prevention and Policy, DOI: $10.3109 / 09687637.2016 .1140720$

farmers to implement eradication. Other reports of widespread human rights abuses of highland peoples at the hands of the military and police may suggest that the intervention was far more repressive than is publicly acknowledged (Windle, 2012b). This said, arrest and prosecution were officially reserved for systematic re-cultivation (Chapon, 1992; Rapin et al., 2003). Farmers were, however, 'administratively punished'. For example, farmers could be placed under increased surveillance or ordered to live (possible under house arrest) and work in specified areas (US State Department, 1999).

Coercive negotiations did effectively wipe out opium production. Within a decade, Vietnam went from being designated a significant source of opium to having essentially eliminated production (Windle, 2012b). The intervention, however, worsened opium farmers living conditions, forcing many to sell land and/or migrate (Corlin, 2004; Windle, 2012b). In some highland areas, an emerging tourism industry represented the only alternative income for opium farmers (Michaud \& Turner, 2000).

\section{Drug crop suppression in Thailand}

Like Vietnam, Thailand succeeded in suppressing opium production in the early-2000s; after decades of cultivation. Where the two differ is that Thai opium suppression - after learning from early policy misunderstandings, mistakes and experiments (Renard, 2009) - centred primarily on alternative development which addressed the structural drivers of opium farming; supported by law enforcement sequenced after state extension and the resolution of the highland insurgency (Windle, 2015b, 2016).

Opium production in Thailand remained a cottage industry until the 1950s (Morlock, 1944) when traditional producers of opium living across Southeast Asia responded to a gap in the global market created by the removal of three of the world's largest sources of illicit opium: China, India and Iran (McCoy, 2003; Renard, 2001). ${ }^{\text {vii }}$ While production was officially prohibited in 1959 a combination of weak authority and high-level connivance with the opiate trade facilitated an increase in production; peaking in 1970 at 200 metric tons over 10,000 hectares (Windle, 2016). 
James Windle (2016): Security trumps drug control: How securitization explains drug policy paradoxes in Thailand and Vietnam, Drugs: Education, Prevention and Policy, DOI: $10.3109 / 09687637.2016 .1140720$

Between 1960 and 1968 the Thai military employed repressive law enforcement techniques against opium farmers in areas with high communist insurgent activity. As law enforcement represented a means of strangling the insurgent's financial resources this early intervention centred upon forced eradication; including napalming villages and planting landmines in poppy fields (Economist, 1969; Kanjan \& Kaewchote, 2004). While increased risk, manufactured by military force, reduced production in some areas the intervention pushed farmers deeper into poverty and further away from the state (Renard, 2001).

By 1968, politicians began to see coercion as counterproductive to counterinsurgency objectives (Economist, 1969; Marks, 1973). As such, Thailand began administering limited development aid and constructing roads to expose the highlands. Then, in 1969, King Bhumibol Adulyadej initiated a highland development project with the primary objective of improving the welfare of highland opium farmers; a joint Thai-UN administered project followed in 1971. These two early projects established a foundation of knowledge of highland issues and agriculture, best practice in administrating highland development and, mutual trust between the state and isolated highland peoples. A number of development projects were administered from the 1970s that brought modern agriculture, market access and social goods to highland communities (Windle, 2016).

In order to allow space for rural development, laws prohibiting opium were seldom enforced before 1983. After which, law enforcement centred crop eradication only once farmers had access to alternative livelihoods. The arrest and punishment of farmers remained minimal throughout the intervention (Renard, 2001). The majority of eradication was negotiated (Chotpimai, 1987) and centred upon the use of levers, such as offering favourable treatment when applying for Thai citizenship (Renard, 2001). As schedules of development/eradication were often negotiated with communities at the beginning of development projects, communities tended to be pre-warned of forced eradication; sometimes years in advance (Lee, 1994). All eradication, whether forced or voluntary, tended to be humane (Lee, 1994; Renard, 2001) and few farmers were arrested or punished for production (DEA, 1992). To avoid impoverishing farmers the Thai Army supplied basic emergency relief after the first eradication (Chotpimai, 1987). 
James Windle (2016): Security trumps drug control: How securitization explains drug policy paradoxes in Thailand and Vietnam, Drugs: Education, Prevention and Policy, DOI: 10.3109/09687637.2016.1140720

In 1999, the U.S. Department of State (1999) removed Thailand from its major drug producers list and UNODC (2009) declared Thailand 'poppy-free' in 2002. Between the peak of production in 1970 and 2010, production declined by $98 \%$. Overall, the intervention had a positive impact on opium farming communities in terms of economic development and access to social goods (Windle, 2016).

\section{Discussion}

This paper has shown how two countries with very similar philosophies, policies and practices towards drugs and, drug users and sellers can take very different paths on specific elements of drug policy, in this case harm reduction and drug crop suppression. This section will provide a tentative hypothesis regarding the choices made: Security trumps drug control.

By this we mean that policies to counter opium production in Thailand, and HIV linked to intravenous drug use in Vietnam, followed the securitization process first proposed by Wæver (1995), and developed by Buzan, Wæver and de Wilde (1998). During the securitization process an actor or actors - whether government, NGO or media - perform a 'speech act' in which an issue is presented as an existential threat which requires moving 'beyond the rules of the game' (Buzan et al., 1998:23). The word security does not necessarily have to be used in the speech: words the audience may link to security can suffice (i.e. defence, threat, war). To become securitized the audience must accept the issue as a security threat. Securitizing the issue in this way elevates it and permits the state to break its own norms of behaviour (Buzan et al., 1998), and may result in the reformulation of new norms (Abrahamsen, 2005). While securitization often increases coercive responses - such as war, intrusive surveillance or state terrorism (Abrahamsen, 2005) - the securitization processes in Thailand and Vietnam resulted in less repressive actions by breaking established ultra-prohibitionist norms.

While drug policy in Southeast Asia tends to be motivated by a mixture of morality and crime control (see Amon et al., 2014), the public health and criminal justice concerns around drug use and distribution can be securitized. The Association of Southeast Asian States (ASEAN) has provided a 
James Windle (2016): Security trumps drug control: How securitization explains drug policy paradoxes in Thailand and Vietnam, Drugs: Education, Prevention and Policy, DOI: $10.3109 / 09687637.2016 .1140720$

number of speech acts presenting drugs as an existential threat. For example, the Joint-Declaration for a Drug-Free ASEAN - signed by Thailand and Vietnam - states:

... the illicit drug trade ... could escalate to such a level where perpetrators can pose serious political and security threats to the region (ASEAN, 1998: preamble, italics added)

The ASEAN Leaders Declaration on a Drug-Free ASEAN - signed by the leaders of Thailand and Vietnam at a meeting in Bangkok - agreed:

... the international drug problem remains one of the main security concerns to all ASEAN Member States... illicit drug abuse and trafficking weaken the social fabric of nations, represent direct and indirect economic costs to governments and entail criminal activities which could threaten the stability of states... (ASEAN, 2012: preamble, italics added).

The securitization of drug policy often results in more militaristic or repressive measures; often causing significant negative consequence (Crick, 2012). Examples include, Thaksin's 'War on Drugs' in Thailand, Widodo's 'state of emergency' on drugs in Indonesia (see Stoicescu \& BurkeShyne, 2015) and the current militarisation of policing in Russia (Galeotti, 2015). Drug control can also, however, be undermined by more traditional security concerns. For example, the U.S. facilitated the production and distribution of illicit drugs to fulfil security objectives in Southeast Asia during the Vietnam War (see McCoy, 2003). Thailand followed a similar path until the 1970s. During the 1950s the Thai military developed a symbiotic relationship with anti-communist insurgent groups engaged in heroin manufacturing and distribution along the Thai-Burmese border. The goal of the relationship was to establish a buffer zone against Burma and weaken the Burmese Government. By the late1970s, however, the Thai Government began viewing their client insurgents as a threat to state authority in border areas. Consequently, in the early-1980s, the military ejected the insurgents from 
James Windle (2016): Security trumps drug control: How securitization explains drug policy paradoxes in Thailand and Vietnam, Drugs: Education, Prevention and Policy, DOI: $10.3109 / 09687637.2016 .1140720$

Thai territory through aerial bombings, military assaults and intensified interdiction of heroin laboratories along the Thai-Burmese border (see McCoy, 2003; Windle, 2016). The cases of opium suppression in Thailand and HIV in Vietnam, however, suggest securitization as a process of implementing more humane policies which break ultra-prohibitionist norms.

Between the early-1960s and early-1980s Thailand experienced a communist insurgency in the northern highlands. The politics of the Cold War meant that Thailand came under significant external pressure to suppress the insurgency, and became the recipient of considerable military aid (Girling, 1967). Furthermore, there was 'an atmosphere of panic' within the Thai Government and military (Handley, 2006: 185) that the insurgents could further destabilise areas bordering antagonistic neighbouring states, some of whom were communist. That is, the civilian government, military and foreign allies identified the insurgency and lack of control over the highlands as a major security threat (see Handley, 2006; McCoy, 2003; Thomas, 1986).

As such, during the 1960s, Thailand attempted to forcefully eradicate opium cultivated in the northern highlands; partly to remove funds from insurgent coffers. Officials based in northern provinces and the Border Patrol Police, however, soon realised that opium suppression pushed farmers towards insurgents in strategically important border areas (Economist, 1969; Campbell, 1983). Morey (2014:73), for example, recalls the Thai Defence Minister telling King Bhumibol Adulyadej how violent attempts to end the highland insurgency had failed. The King told the General that the insurgency could be ended by developing rural areas and, providing healthcare and education. This dovetailed a growing identification that most insurgents were motivated not by ideology, but by the material support promised by communist agents (Girling, 1967), and that some local conflicts were a direct result of opium suppression (Culas \& Michaud, 1997). The King became a key proponent of development as a means of suppressing both opium production and the insurgency. $\mathrm{He}$ used securitizing speech acts to advocate this policy:

Attempts should be made to bring over the people to our side so that they will not join [the communists] ... We must firstly provide protection and assistance to them 
James Windle (2016): Security trumps drug control: How securitization explains drug policy paradoxes in Thailand and Vietnam, Drugs: Education, Prevention and Policy, DOI: $10.3109 / 09687637.2016 .1140720$

in various ways, and this is the policy to push back the terrorists (cited in

Grossman \& Faulder, 2012: 240).

People who are hungry and sick are receiving help from people who are ... terrorists. So we have to give help immediately (cited in Grossman \& Faulder, 2012: 247)

Many are driven into becoming insurgents by force of circumstance ... It is up to officials in rural areas to perform their duty with caution, justice, consciousness and greater sacrifice. Otherwise we have to concede victory to the insurgents (cited in Handley, 2006: 199).

These thoughts translated into policy when Prime Minister Tinsulanonda issued two policy guidelines (Order no. 66/2523 and 65/2525) stressing development as more effective than military force in suppressing the insurgency. The policy was based upon the 'assumption that such development would undercut popular support for the insurgents and also provide a rationale for many insurgents to defect' (Thomas, 1986: 21).

Linked to the insurgency, Thailand sought to extend state authority into highland areas, and realised that removing an important key cash crop pushed highland peoples away from the state; whereas rural development would build political capital with isolated highland peoples. That is, by the early-1970s Thailand came to view development as useful in extending the state whilst reducing the insurgent support base and suppressing a prohibited drug crop (see Renard, 2001; Windle, 2016).

Vietnam, on the other hand, had extended its authority over highland opium farming communities and suppressed highland insurgencies decades before it had attempted to suppress opium production. In fact, the continual abuse of highland minorities by the Vietnamese Government (Home Office, 2014) had not destabilised the highlands. That is, as it did not need development to extend the state it was free to use more coercive methods (Windle, 2012, 2016) which conformed to Vietnams zero-tolerance approach. 
James Windle (2016): Security trumps drug control: How securitization explains drug policy paradoxes in Thailand and Vietnam, Drugs: Education, Prevention and Policy, DOI: 10.3109/09687637.2016.1140720

In summary, when repressive drug crop suppression conflicted with Thailand's security agenda it was replaced with a more humane development-orientated approach. Whereas, the stability of the Vietnamese highlands meant that the government could quickly suppress opium using coercive means, without igniting a security risk.

In terms of harm reduction it appears that Vietnam identified HIV as a threat to national security. The linkage between HIV and security is founded upon the fear that HIV within the military could reduce military power, and that high HIV rates amongst the general population could eventually result in state collapse; which could, in turn, facilitate more traditional security threats. It's a perception held by many governments, and one promoted by the U.S. since the 1980s (Barnett, 2008; de Waal, 2010). For example, UN Security Council Resolution 1308 states: 'the HIV/AIDS pandemic, if unchecked, may pose a risk to stability and security' (UN Security Council, 2000). While, in 2000, James Wolfensohn, the former president of the World Bank, called HIV the greatest 'challenge to peace and stability in African societies ... We face a ... a security crisis' (cited in Ancker, 2007:34). Premier Wen of China stated in 2004 that HIV 'has great bearing on the strength of the Chinese nation and the fate of the country' (cited in Morey, 2014:176).

The security / HIV link has been contested by academics (see Barnett, 2008; Fourie, 2007; for support see Ancker, 2007; McInnes \& Rushton, 2010; Singer, 2002). Evidence is not, however, necessary for policy (Monaghan, 2011) and 'governance outcomes have been shaped as much by the perception of HIV/AIDS as a security threat, as the actual impacts of the epidemic' (de Waal, 2010:114). The linkage promoted by the Security Council was influential. It resulted in the formation of: a UN General Assembly Special Session on HIV/AIDS in 2001; the G8 Global Fund to Fight HIV/AIDS, Tuberculosis and Malaria in 2002; and the President's Plan for Emergency AIDS Relief in 2003. The U.S. military continue to invest heavily in the development of a HIV vaccine (McInnes \& Rushton, 2010). That is, while the link may have been overstated, re-labelling HIV a security threat elevated it as a priority policy area on the international stage.

The international bodies created to contain the security threat of HIV all worked in Vietnam during the late-1990s/2000s, and likely influenced the perception of HIV as a security threat. In fact, a 
James Windle (2016): Security trumps drug control: How securitization explains drug policy paradoxes in Thailand and Vietnam, Drugs: Education, Prevention and Policy, DOI: 10.3109/09687637.2016.1140720

turning point in Vietnamese policy was when the Vice Prime Minister attended a UNDP sponsored

conference. One participant recalls how a Thai speaker:

... talked about how devastating AIDS was in the Thai military, and on hearing this, the Vietnamese Vice Prime Minister sent his aid out to make a call to a general to attend the conference and talk to Mechai [the speaker a, Thai Cabinet Minister] (Morey, 2014:218).

A UNDP delegate then told the conference 'Vietnam has fought many wars in its history, but the war against HIV/AIDS could be the most challenging of all'. The Vice Prime Minister went on to become the head of Vietnams National AIDS Task Force (Morey, 2014:218, italics added) and a key proponent of harm reduction.

Vietnam has linked drugs to HIV and security by referring to drugs as 'creating bad effects on society's culture, public security and contributing to the spread of HIV' (cited in Ha et al., 2010, italics added). The opening paragraph of Prime Ministers Decision 36/2004/QD-TTG represents a securitizing speech act presenting HIV as an existential threat:

HIV/AIDS is a dangerous epidemic, threatening people's health and life and the future generations of the nation. HIV/AIDS directly affects the country's economic and cultural development, social order and safety (Government of Vietnam, 2004: 1 , italics added).

Indeed, this is reflected in Vietnam's 2004 National Strategy on HIV/AIDS Prevention which states: 'HIV/AIDS ... undermines security, development and the human race' (Government of Vietnam 2004:12, italics added).

Why then did Thailand not roll out harm reduction policies, when it too had a significant HIV population? The answer may lie in the drugs of choice and modes of ingestion. Vietnam's most widely consumed drug is heroin, intravenous use is the most common mode of ingestion, and the HIV 
James Windle (2016): Security trumps drug control: How securitization explains drug policy paradoxes in Thailand and Vietnam, Drugs: Education, Prevention and Policy, DOI: $10.3109 / 09687637.2016 .1140720$

epidemic is concentrated around people who inject drugs (Ha et al., 2010; Open Society, 2007).

Whereas, Thailand's most widely consumed drug is yaa baa, which is mostly smoked or swallowed; although there is a significant injecting population (see Hayashi et al., 2011; UNODC, 2011, 2015). Furthermore, Thailand was able to significantly reduce the number of people infected with HIV through extensive prevention and treatment campaigns without implementing harm reduction. It may be significant that by the mid-1990s Thailand had already made impressive reductions in HIV rates within the military (Rojanapithayakorn \& Hanenberg, 1996).

It may be that once HIV was labelled a security risk in Vietnam, the state was able to break its ultra-prohibitionist norms. Alternatively, as the number of injecting drug users was lower in Thailand, and Thai policy had so far contained the threat without including people who inject drugs, it did not have to reassesses its underlying ultra-prohibitionist philosophy.

Herrington (2010) has argued that HIV was not securitized in Vietnam as the state pushed for more social, rather than coercive, means to contain the issue. Coercion is not, however, a prerequisite of securitization: breaking of norms of behaviour is enough. In this case harm reduction broke zero tolerance policies founded upon an ultra-prohibitionist philosophy; as did development-orientated opium suppression in Thailand. Furthermore, as Abrahamsen (2005) and McInnes and Rushton (2010) have argued, security and normal politics are not binary positions but rather represent ends of the spectrum: HIV and opium may have been partly securitized.

This all said, the policy process is messy and complex, and seldom limited to one consideration, no matter how influential (Lancaster et al., 2014). Thai HIV policy was, for example, influenced by a strong and active civil society who sought to tackle the disease because of the harm caused to individuals and communities (Lyttleton, 2008); not because it was a security threat. The Kings labelling of rural development in opium farming areas as a response to a security threat was additionally motivated by his compassion for opium farmers (Grossman \& Faulder, 2012; Morey, 2014). Conversely, public opinion can also be a significant driver of policy. And tough drug policy is popular in Thailand and Vietnam.

In short, policy is not always arrived at through rational processes that weigh up costs and benefits (Monaghan, 2011). Rather policy is often an outcome of years or decades of institutional 
James Windle (2016): Security trumps drug control: How securitization explains drug policy paradoxes in Thailand and Vietnam, Drugs: Education, Prevention and Policy, DOI: $10.3109 / 09687637.2016 .1140720$

learning (Windle, 2013) and interaction between bureaucratic, economic and moral entrepreneurs with

different and conflicting objectives (Windle, 2014). That may be, however, until the problem is securitised. For once labelled a security threat the state must act immediately: to fail to do so could threaten the very existence of a thing of great importance and, as such, necessitates the overcoming of norms of behaviour (Buzan et al., 1998). That is, popular ultra-prohibitionist norms were broke in response to the perceived security threats of HIV in Vietnam and highland insurgency in Thailand.

\section{Conclusion}

This paper has demonstrated how two countries with similar ultra-prohibitionist foundations took different paths regarding harm reduction and drug crop suppression. Thailand implemented a humane drug crop suppression intervention, and a repressive policy against consumers which largely ignored harm reduction. Vietnam has begun to implement harm reduction practices, yet its drug crop suppression intervention was repressive.

It can be difficult to uncover what motivates governments to formulate policy, especially former communist states (Ha et al., 2010; Vuong et al., 2012). It has, however, been suggested that labelling specific drug policy issue security threats resulted in significant policy change that went against established drug policy norms.

Thailand and Vietnam took very different approaches to opium suppression and the differences were largely guided by security concerns. Thailand broke its own ultra-prohibitionist norms when repressive drug crop suppression began inflating the insurgency and destabilising border areas. Vietnam, on the other hand, had already extended its authority over highland opium farming communities and suppressed highland insurgencies, so was free to use more coercive means.

While both Thailand and Vietnam identified HIV as a security threat, Thailand reduced the threat without changing its underlying philosophy. The high level of intravenous drug consumption in Vietnam, however, forced the Vietnamese Government to accept harm reduction as useful for reducing the perceived security threat of HIV. 
James Windle (2016): Security trumps drug control: How securitization explains drug policy paradoxes in Thailand and Vietnam, Drugs: Education, Prevention and Policy, DOI: $10.3109 / 09687637.2016 .1140720$

That is, the speech acts of implying intravenous drugs use and HIV and, opium cultivation and insurgency, as security threats necessitated the breaking of the rules of the ultra-prohibitionist game. These two case, furthermore, demonstrate how securitization is not binary and does not necessarily end in the use of force. The 'rules of the game' were indeed broke; but broke in a more positive way which resulted in more humane policy.

\section{References}

Abrahamsen, R. (2005). Blair's Africa: The politics of securitization and fear. Alternatives, 30, 55-80.

ASEAN (1998) Joint-declaration for a drug-free ASEAN. Retrieved from

http://www.asean.org/communities/asean-political-security-community/item/joint-declarationfor-a-drug-free-asean

ASEAN (2012) ASEAN leaders declaration on a drug-Free ASEAN. Retrieved from http://www.asean.org/archive/documents/Declaratin\%20on\%20Drug\%20Free\%20ASEAN_E ndorsed\%20by\%20Summit_FINAL.pdf

Amon, J.J., Pearshouse, R., Cohen, J.E. \& Schleifer, R. (2014). Compulsory drug detention in East and Southeast Asia: Evolving government, UN and donor responses. International Journal of Drug Policy, 25, 13-20.

Ancker, S. (2007). HIV/AIDS: Security threat in Central Asia? China and Eurasia Forum Quarterly, $5,33-50$.

Avert (2014). HIV and AIDS in Thailand. Retrieved from http://www.avert.org/hiv-aids-thailand.htm

Barrett, M.D., Thomson, N. and Aramrattana, A. (2010). Rapid assessment and response: Preparation for the scale-up of comprehensive harm reduction services in Thailand. Retrieved from http://idpc.net/publications/2010/06/rapid-assessment-and-response-harm-reduction-thailand

Barnett, T. (2008). A long wave event: HIV/AIDS, politics, governance and 'security': Sundering the intergenerational bond? In M. Follér \& H. Thörn (Eds.). The politics of AIDS: globalization, the state and civil society. London: Palgrave. 
James Windle (2016): Security trumps drug control: How securitization explains drug policy paradoxes in Thailand and Vietnam, Drugs: Education, Prevention and Policy, DOI: 10.3109/09687637.2016.1140720

Boonwaat, L. (2001). An overview of alternative development and illicit crop eradication policies, strategies and actions in the region. Regional Seminar on Alternative Development for Illicit Crop Eradication Policies, Strategies and Actions 16-19 July 2001. Myanmar: UNDCP.

Buzan, B., Wæver, O. \& de Wilde, J. (1998). Security a new framework for analysis. London: Lynne Rienner.

Campbell, C. (1983). Thais hesitate to wreck opium fields of tribes. New York Times, 20 February. Cates, W. (2013). A world without AIDS? A promising approach is bringing Vietnam closer. The Huffington Post, November 26, 2013.

Chapon, J. (1992). Opium ravages Northern Vietnam province. Agence France Presse, 24 April 1992.

Chan, K.Y., Stoové, M.A. \& Reidpath, D.D. (2008). Stigma, social reciprocity and exclusion of HIV/AIDS patients with illicit drug histories: A study of Thai nurses' attitudes. Harm reduction Journal, 5(1).

Chotpimai, Y. (1987). Third Army area narcotics crops cultivation control programme. Regional Seminar on Replacement of Opium Poppy Cultivation December 14-19 1987. Chiang Mai; UNDP.

Crick, E. (2012). Drugs as an existential threat: An analysis of the international securitization of drugs. International Journal of Drug Policy, 23, 407-414.

Corlin, C. (2004). Hmong and the land question in Vietnam: National policy and local concepts of the environment. In N. Tapp, J. Michaud, C. Culas \& G.Y. Lee (Eds.). Hmong/Miao in Asia. Chiang Mai: Silkworm Books.

Csete, J., Kaplan, K., Hayashi, K., Fairbairn, N., Suwannawong, P., Zhang, R., Wood, E., \& Kerr, T. (2011). Compulsory drug detention center experiences among a community-based sample of injection drug users in Bangkok, Thailand. BMC International Health and Human Rights, 11.

Culas, C. \& Michaud, J. (1997). A contribution to the study of Hmong (Miao) migrations and history.

Bijdragen tot de Taal-, Land- en Volkenkunde, 153, 211-243.

DEA (1992). Worldwide heroin situation. Washington: US Department of Justice.

Economist (1969). Thailand: The other rebellions. The Economist, 29 March 1969. 
James Windle (2016): Security trumps drug control: How securitization explains drug policy paradoxes in Thailand and Vietnam, Drugs: Education, Prevention and Policy, DOI: 10.3109/09687637.2016.1140720

Fairbairn, N., Hayashi, K., Kaplan, K., Suwannawong, P., Qi, J., Wood, E. \& Kerr, T. (2012) Factors associated with methadone treatment among injection drug users in Bangkok, Thailand. Journal of Substance Abuse Treatment, 43, 108-113.

Fourie, P. (2007). The relationship between the AIDS pandemic and state fragility. Global Change, Peace \& Security, 19, 281-300.

Galeotti, M. (2015). Narcotics and nationalism: Russian drug policies and futures. Retrieved online: http://www.brookings.edu/ /media/Research/Files/Papers/2015/04/global-drugpolicy/Galeotti--Russia-final.pdf?la=en

Girling, J.L. (1968). Northeast Thailand: Tomorrow's Vietnam? Foreign Affairs, 46, 388-97.

Government of Thailand (2014). 2014 Thailand AIDS response progress report reporting period 2012-2013. Retrieved from http://www.unaids.org/sites/default/files/country/documents//THA_narrative_report_2014.pdf Government of Vietnam (1992). Constitution of the Socialist Republic of Vietnam. Retrieved from http://www.na.gov.vn/htx/English/C1479/\#BSi1T823Fk4U

Government of Vietnam (2000). The law on preventing and combating narcotic drugs. Retrieved from http://www.unodc.org/enl/showDocument.do?documentUid=2304\&cuntry=VIE

Government of Vietnam (2004). National strategy on HIV/AIDS prevention and control in Vietnam until 2010 with a vision to 2010: Promulgated together with Prime Ministers decision No. 36/2004/QD-TTg. Retrieved from:

http://www.vaac.gov.vn/Desktop.aspx/Content/Publicationdata/The_National_Strategy_on_HIVAIDS_Prevention_and_Control_in_Viet_Nam_till_2010 _with_a_Vision_to_2020/

Government of Vietnam (2006). Law on AIDS/HIV prevention and control. Retrieved from http://test.aidsportal.org/atomicDocuments/AIDSPortalDocuments/VietnamGovLawHIVPrev entionControl2006.pdf

Government of Vietnam (2013). Results of national HIV sentinel surveillance. Vietnam: Ministry of Health. 
James Windle (2016): Security trumps drug control: How securitization explains drug policy paradoxes in Thailand and Vietnam, Drugs: Education, Prevention and Policy, DOI: $10.3109 / 09687637.2016 .1140720$

Government of Vietnam (2014). Viet Nam AIDS response progress report 2014: Following up the 2011 political declaration on HIV/AIDS. Retrieved from

http://www.aidsdatahub.org/sites/default/files/publication/Vietnam narrative report 2014.pdf

Grossman, N., \& Faulder, D. (2012). King Bhumibol Adulyadej: A life's work. Bangkok: Editions Didier Millet.

Ha, P.N., Pharris, A., Huaong, N.T., Chuc, N., Brugha, R. \& Thorson, A. (2010). The evolution of HIV policy in Vietnam: From punitive control measures to a more rights-based approach. Global Health Action, 3.

Handley, P.M. (2006). The King never smiles: A biography of Thailand's Bhumibol Adulyadej. London: Yale University Press.

Hammett, T., Wu, Z., Duc, T.T., Stephens, D., Sullivan, S., Liu, W., Chen, Y., Ngu, D. \& Jarlais, D. (2008). 'Social evils' and harm reduction: The evolving policy environment for human immunodeficiency virus prevention among injection drug users in China and Vietnam. Addiction, 103, 137-145.

Hayashi, K. (2013). Policing and public health: Experiences of people who inject drugs in Bangkok, Thailand. Retrieved from http://journals.plos.org/plosmedicine/article?id=10.1371/journal.pmed.1001570

Hayashi, K., Wood, E., Suwannawong, P., Kaplan, K., Qi, J., \& Kerr, T. (2011). Methamphetamine injection and syringe sharing among a community-recruited sample of injection drug users in Bangkok, Thailand. Drug and Alcohol Dependence, 115, 145-149.

Hayes-Larson, E., Grau, L., Khoshnood, K., Barbour, R., Khuat, O. \& Heimer, R. (2013). Drug users in Hanoi, Vietnam: Factors associated with membership in community-based drug user groups. Harm Reduction Journal, 10.

Herington, J. (2010). Securitization of infectious diseases in Vietnam: The cases of HIV and avian influenza. Health Policy and Planning, 25, 467-475.

Home Office (2014). Country information and guidance Vietnam: Ethnic minority groups. Retrieved online 
James Windle (2016): Security trumps drug control: How securitization explains drug policy paradoxes in Thailand and Vietnam, Drugs: Education, Prevention and Policy, DOI: 10.3109/09687637.2016.1140720 https://www.gov.uk/government/uploads/system/uploads/attachment_data/file/389930/CIG.Vi etnam.Ethnic_Minority_Groups.v1.0.pdf

Human Rights Watch and Thai AIDS Treatment Action Group (2007). Deadly denial. Retrieved from http://www.hrw.org/sites/default/files/reports/thailand1107.pdf

Human Rights Watch (2004). Thailand: Not enough graves: The War on Drugs, HIV/AIDS, and violations of human rights. Retrieved from http://www.refworld.org/docid/412efec42.html Human Rights Watch (2009). Thailand: Convictions of police in drug campaign abuse a 'first step'. Retrieved from http://www.hrw.org/news/2009/12/14/thailand-convictions-police-drugcampaign-abuse-first-step

Human Rights Watch (2011). The Rehab Archipelago. Forced labor and other abuses in drug detention centres in Southern Vietnam. Retrieved from http://www.hrw.org/reports/2011/09/07/rehab-archipelago-0

Hunt, N., Ashton, M., Lenton, S., Mitcheson, L., Nelles, B. \& Stimson, G. (2003). A review of the evidence-base for harm reduction approaches to drug use. Retrieved from http://neilhunt.org/pdf/2003-evidence-base-for-hr-hunt-et-al.pdf

IPDC (International Drug Policy Consortium) (2014). Thailand's drug control agency announces new harm reduction strategy. Retrieved from: http://idpc.net/publications/2014/04/thailand-sdrug-control-agency-announces-new-harm-reduction-strategy

IRIN (2014). Compulsory detention for drug use undermines treatment in Laos. IRIN, August 19 2014. Retrieved from http://www.irinnews.org/report/98920/compulsory-detention-for-drug$\underline{\text { use-undermines-treatment-in-laos }}$

Jardine, M., Crofts, N., Monaghan, G. \& Morrow, M. (2012). Harm reduction and law enforcement in Vietnam: Influences on street policing. Harm Reduction Journal, 9.

Kanjan, C. \& Kaewchote, J. (2004). Communities for watershed protection. Asia Forest Network. Retrieved from www.asiaforestnetwrok.org

Kerr, T., Hayashi, K., Ti, L., Kaplan, K., Suwannawong, P. \& Wood, E. (2014). The impact of compulsory drug detention exposure on the avoidance of healthcare among injection drug users in Thailand. International Journal of Drug Policy, 25, 171-174. 
James Windle (2016): Security trumps drug control: How securitization explains drug policy paradoxes in Thailand and Vietnam, Drugs: Education, Prevention and Policy, DOI: 10.3109/09687637.2016.1140720

Lancaster, K., Ritter, A. \& Colebatch, H. (2014). Problems, policy and politics: Making sense of

Australia's 'ice epidemic'. Policy Studies, 35, 147-171.

Lee, R. (1994). Controlling production of opiates: The case of Thailand. The Economics of the

Narcotics Industry Conference. Washington: U.S. Department of State.

Lenton, S. \& Single, E. (1998). The definition of harm reduction. Drug and Alcohol Review, 17, 213219.

Levine, H.G. (2003). Global drug prohibition: its uses and crises. International Journal of Drug Policy, 14, 145-153.

Lyttleton, C. (2008). AIDS and civil belonging: Converging currents in Thailand and Laos. In M.

Follér \& H. Thörn (Eds.). The politics of AIDS: globalization, the state and civil society.

London: Palgrave.

MacDonald, V. \& Nacapew, S. (2013). Drug control and harm reduction in Thailand. Retrieved from: http://idpc.net/publications/2013/11/idpc-briefing-paper-drug-control-and-harm-reduction-inthailand

Malikaew, S. (2014). Harm reduction: A lifeline for drug users we cannot afford to lose, The Nation, 27 June 2014.

Marks, T. (1973). The Meo Hill tribe problem in North Thailand. Asian Survey, 13, 929-944.

McCoy, A. (2003). The politics of heroin: CIA complicity in the global drug trade. Chicago: Lawrence Hill Books.

McInnes, C. \& Rushton, S. (2010). HIV, AIDS and security: Where are we now? International Affairs, $86,225-245$.

Michaud, J. \& Turner, S. (2000). The Sa Pa Marketplace, Lao Cai Province Vietnam. Asia Pacific Viewpoint, 41, 85-100.

Monaghan, M. (2011). Evidence versus politics: Exploiting research in UK drug policy making? Bristol: Policy Press.

Morey, R.D. (2014). The United Nations at work in Asia: An envoy's account of development in China, Vietnam, Thailand and the South Pacific. Jefferson: McFarland and Company. 
James Windle (2016): Security trumps drug control: How securitization explains drug policy paradoxes in Thailand and Vietnam, Drugs: Education, Prevention and Policy, DOI: 10.3109/09687637.2016.1140720

Morlock, G.A. (1944). Limitation on the production of opium. Department of State Bulletin, 6(285):

723-727. British National Archives, Kew London: FO 371/50647.

Nguyen, V. \& Scannapieco, M. (2008). Drug abuse in Vietnam: A critical review of the literature and implications for future research. Addiction, 103, 535-543.

Nutt, D.J., King, L.A. \& Phillips, L.D. (2010). Drug harms in the UK: A multicriteria decision analysis. The Lancet, 376, 1558-1565.

ONCB (Office of the Narcotics Control Board) (2007). National narcotics control policy on Kingdom's unity for victory over drugs strategy. Retrieved from http://en.oncb.go.th/file/information_policy.html

ONCB (Office of the Narcotics Control Board) (2011). Thailand narcotics control annual report 2011. Bangkok: Ministry of Justice.

Open Society (2007). HIV/AIDS policy in Vietnam. Retrieved from http://www.opensocietyfoundations.org/publications/hivaids-policy-vietnam-civil-societyperspective

Pankonin, C., Higgs, P., Reid, G., \& Aitken, C. (2008). Selling syringes to injecting drug users: A study of five pharmacies in Hanoi, Vietnam, The Journal of Infection in Developing Countries, 2, 51-58

Pearshouse, R. (2009). Compulsory drug treatment in Thailand: Observations on the narcotic addict rehabilitation act I B.E. 2545 (2002). Canadian HIV/AIDS Legal Network. Retrieved from http://www.aidslaw.ca/publications/interfaces/downloadFile.php?ref=1429

Pinkham, S. \& Stone, K. (2015). A global review of the harm reduction response to amphetamine: A 2015 update. Retrieved from http://www.ihra.net/files/2015/10/18/AmphetaminesReport_Oct2015_web.pdf

Rapin, A., Khue, D.H., Duc, D.N., Eyres, J., Tran, V.C., Higgs, P. \& Duan, N.V. (2003). Ethnic minorities, drug use and harm in the highlands of Northern Vietnam: A contextual analysis of the situation in six communes from Son La, Lai Chau, and Lao Cai. Bangkok: UNODC.

Renard, R. (2001). Opium reduction in Thailand 1970-2000: A thirty year journey. Chiang Mai: Silkworm Books. 
James Windle (2016): Security trumps drug control: How securitization explains drug policy paradoxes in Thailand and Vietnam, Drugs: Education, Prevention and Policy, DOI: 10.3109/09687637.2016.1140720

Renard, R.D. (2009). Mainstreaming Alternative Development in Lao PDR, Myanmar and Thailand:

A Process of Learning. Bangkok: UNODC.

Rojanapithayakorn, W. \& Hanenberg, R. (1996). The 100\% condom program in Thailand. AIDS, 10, $1-7$.

Roxburgh, A., Ritter, A., Slade, T. and Burns, L. (2013). Trends in drug use and related harms in Australia, 2001 to 2013. Sydney: University of New South Wales.

Singer, P.W. (2002). AIDS and international security. Survival, 44, 145-158.

States News Service (2014). Drug detention centres offer torture, not treatment. States News Service, July 24, 2014.

Stoicescu, C. \& Burke-Shyne, N. (2015). Academics come out in force against Indonesia's drug crackdown. Retrieved from https://www.opensocietyfoundations.org/voices/academics-comeout-force-against-indonesia-s-drug-crackdown

Thai News Service (2014). Vietnam: Party Secretariat Calls for Stronger Leadership to Prevent Drugs Crime. Thai News Service, April 16th 2014.

The Nation (2014). Time to declare truce in 'war on drugs', The Nation, 23 May 2014.

The Telegraph (2014). Vietnam Sentences 30 Heroin Smugglers to Death in Biggest Drugs Trial. The Telegraph 20th January 2014.

Thomas, M. L. (1986). Communist insurgency in Thailand: Factors contributing to its decline. Asian Affairs, 13, 17-26.

Tran, B.X. (2013). Willingness to pay for methadone maintenance treatment in Vietnamese epicenters of injection-drug driven HIV infection. Bulletin of the World Health Organization, 91, 475482.

Tyndal, M. (2010). Harm reduction policies and interventions for injecting drug users in Thailand. Bangkok: World Bank.

UNAIDS (2014). The gap report. Geneva: UNAIDS.

UN Security Council (2000). Resolution 1308 (2000) on the responsibility of the Security Council in the maintenance of international peace and security: HIV/AIDS and international peacekeeping operations. Retrieved from 
James Windle (2016): Security trumps drug control: How securitization explains drug policy paradoxes in Thailand and Vietnam, Drugs: Education, Prevention and Policy, DOI: 10.3109/09687637.2016.1140720

http://www.unaids.org/sites/default/files/sub_landing/files/20000717_un scresolution 1308 e

$\underline{\text { n.pdf }}$

UNICEF (United Nations Children's Fund) (2014). Thailand: Overview. Retrieved from http://www.unicef.org/thailand/hiv_aids.html

UNODC (UN Office of Drugs and Crime) (2009). Opium poppy cultivation in Southeast Asia. Bangkok: UNODC.

UNODC (2011). Patterns and trends of amphetamine-type stimulants and other drugs: Asia and Pacific. Vienna: UNODC.

UNODC (2012). Viet Nam communes trials community-based drug dependence treatment. Bangkok: UNODC.

UNODC (2013). Regional programme for Southeast Asia 2014-2017. Bangkok: UNODC.

UNOD (2014a). World drug report. Vienna: UNODC.

UNODC (2014b). World drug day 2014. Retrieved from

http://www.unodc.org/unodc/en/frontpage/2014/July/world-drug-day-2014_-activities-acrossthe-globe.html

UNODC (2015). The challenges of synthetic drugs in East and Southeast Asia and Oceania.

Retrieved from

https://www.unodc.org/documents/southeastasiaandpacific/Publications/2015/drugs/ATS_201

5_Report_web.pdf

U.S. State Department (1999). Country reports on human rights practices. Washington: State Department.

Vuong, T., Ali, R., Baldwin, S. \& Mills, S. (2012). Drug policy in Vietnam: A decade of change? International Journal of Drug Policy, 23, 319-326.

de Waal, A. (2010). Reframing governance, security and conflict in the light of HIV/AIDS: A synthesis of findings from the AIDS, security and conflict initiative. Social Science \& Medicine, 70, 114-120.

Wæver, O. (1995). Securitization and desecuritization. In R.D. Lipschultze (Ed.). On Security. New York: Columbia University Press. 
James Windle (2016): Security trumps drug control: How securitization explains drug policy paradoxes in Thailand and Vietnam, Drugs: Education, Prevention and Policy, DOI: 10.3109/09687637.2016.1140720

Werb, D., Hayashi, K., Fairburn, N., Kaplan, K., Suwannawong, P. \& Kerr, T. (2009). Drug use

patterns among Thai illicit drug injectors amidst increased police presence. Substance Abuse

Treatment, Prevention, and Policy. Retrieved from

http://substanceabusepolicy.biomedcentral.com/articles/10.1186/1747-597X-4-16

WHO (World Health Organization) (2010). A strategy to halt and reverse the HIV epidemic among people who inject drugs in Asia and the Pacific: 2010-2015. New York: WHO.

Windle, J. (2012). Insights for contemporary drug policy: A historical account of opium control in India and Pakistan. Asian Journal of Criminology, 7, 5-74.

Windle, J. (2012). The suppression of illicit opium production in Viet Nam: An introductory narrative.

Crime, Law and Social Chang, 57, 425-439

Windle, J. (2013). A very gradual suppression: A history of Turkish opium controls, 1933-1974.

European Journal of Criminology, 11, 195-212.

Windle, J. (2014). How the east influenced drug prohibition. The International History Review, 35,

1185-1199

Windle, J. (2015). Drugs and drug policy in Thailand. Retrieved from

http://www.brookings.edu/research/papers/2015/04/global-drug-policy

Windle, J. (2015b). A slow march to harm reduction: Drugs and drug policy in Vietnam. Retrieved from http://www.brookings.edu/research/papers/2015/04/global-drug-policy

Windle J. (2016). Suppressing Illicit Opium Production: Successful Intervention in Asia and the

Middle East. London: I.B. Taurus.

World Bank (2010). Harm reduction policies and interventions for injection drug users in Thailand.

Bangkok: World Bank.

World Bank (2011). Harm reduction policies and interventions for injecting drug users in Thailand.

Washington: World Bank.

Zhang, L., Maher, L., Pham, Q.D., Higgs, P., Anh, N.D., Duc, B.H., Hoa, D.M. \& Wilson, D.P.

(2014). Evaluation of a decade of DFID and World Bank supported HIV and AIDS programmes in Vietnam from 2003 to 2012. Retrieved from 
James Windle (2016): Security trumps drug control: How securitization explains drug policy paradoxes in Thailand and Vietnam, Drugs: Education, Prevention and Policy, DOI: 10.3109/09687637.2016.1140720

https://www.gov.uk/government/uploads/system/uploads/attachment data/file/303560/Decade

-DFID-World-Bank-Support-HIV-Aids-Prog-Vietnam-2003-2012.pdf

Zhang, S. \& Chin, K. (2015). A people's war: China's struggle to contain its illicit drug problem.

Retrieved http://www.brookings.edu/research/papers/2015/04/global-drug-policy

\footnotetext{
${ }^{i}$ The most widely consumed drugs are heroin (Vietnam) and yaa baa (Thailand; methamphetamine pills cut with caffeine), although crystal methamphetamine consumption is rising in both states (see UNODC, 2015; Windle, 2015b, 2015b). For a discussion on the harms associated with methamphetamine and heroin consumption see Roxburgh et al. (2013).
}

ii Harm reduction here:

... refers to policies, programmes and practices that aim primarily to reduce the adverse health, social and economic consequences of the use of legal and illegal psychoactive drugs without necessarily reducing drug consumption (HRI, 2015: no page).

iii While this paper refers to the Thai intervention as humane, this is not to imply that it followed harm reduction principles. Such a conceptual discussion is beyond the scope of this paper, however, as reducing harm was not the interventions primary goal it may be difficult to conceptualise it as harm reduction (see Lenton and Single, 1998).

iv A pilot harm reduction strategy, launched in February 2014, stalled after the 2014 military coup. If implemented it would have supported the distribution of clean needles and coordinated the administration of harm reduction with civil society (IDPC, 2014).

${ }^{v}$ Nationally it is more common to eat or smoke yaa baa pills (UNODC, 2015; World Bank, 2010). There are, however, relatively large methamphetamine injecting populations in some areas (Barrett et al., 2010; Hayashi et al. 2011; UNODC, 2011), including 'poly-drug users who continue to inject, inhale, and ingest a range of illegal drugs' (World Bank, 2010: 5).

See Pinkham and Stone (2015) for a discussion on the range of strategies available for amphetamine consumers.

vi In 2010 the Council of State declared that needle exchanges promote drug use, and are thus inconsistent with Thai drug control law. The ruling forced Prime Minister Vejjajiva to abandon plans for a national harm reduction strategy.

vii During the 1950s China and Iran suppressed the production of opium (Windle, 2016). India strengthened its control over regulated opium production and exportation for the pharmaceutical industry and, although diversion from the state monopoly means that India currently remains one of the world's largest sources of illicit opium, very little exported (Windle, 2012a). 